\title{
マイクロバブルによるテイラー・クエット流れの遷移抑制*
}

\author{
渡 村 友 昭*1, 田坂 裕 司*2 \\ 村 井祐 一*2, 武田靖*2
}

\section{Suppression of the Flow Transition by Microbubbles in a Taylor-Couette Flow}

\author{
Tomoaki WATAMURA*3, Yuji TASAKA, \\ Yuichi MURAI and Yasushi TAKEDA \\ ${ }^{* 3}$ Division of Energy \& Environmental Systems, Graduate School of Engineering, Hokkaido University, \\ N 13 W 8, Kita-ku, Sapporo-shi, Hokkaido, 060-8628 Japan
}

\begin{abstract}
We investigated the interaction between microbubbles and Taylor-vortices, which are generated in a fluid layer between coaxial-rotating double cylinders. $O(10 \mu \mathrm{m})$-diameter hydrogen bubbles were generated by water electrolysis and dispersed into the fluid layer. The maximum void fraction, which is estimated by the input power for the water electrolysis, was smaller than $0.02 \%$. From the time averaged velocity distribution, which is observed by Ultrasonic Velocity Profiling (UVP), these values are changed with different tendency at $R e / R e_{c}=3.0$ or 4.0 , where $R e_{c}$ is the critical Reynolds number for onset of the primary instability. As initially expected, the existence of the microbubbles does not modify the axial wavelength of the vortices and the frequency of the azimuthal waves either. However, the power of the modulation wave component, which comes from the flow instability, is lowered by the addition of microbubbles at $R e / R e_{c}=8.0$. This phenomenon is caused by the rising bubbles with the pattern, which makes inhomogeneous local void fraction.
\end{abstract}

Key Words : Microbubble, Flow Transiton, Vortex, Ultrasonic Velocity Profiling (UVP)

\section{1. 緒}

直径が $1 \mathrm{~mm}$ 以下のマイクロバブルは，僅かな体積 率(ボイド率)で流体物性ならびに流れ場に大きな影響 を与えるとして幅広く研究されている. 化学, 生物学 系の研究としては, 魚介類の養殖, 水の浄化, 化学装 置における反応促進など，省エネ技術の研究としては 例えば船舶の抵抗低減などへの産業利用として注目さ れている(1). 液体に一定体積の気泡を注入する場合, その直径が小さくなることにより単位体積あたりの表 面積 (界面積濃度)が増加する. 気泡表面積の増加は, 液相と気相の間における熱と物質の伝達に大きな影響 を与えるため，気泡を用いた化学装置ではその性能を 左右する，気泡は液相の中を浮上する際に周囲流体を 駆動するが，直径の小さな気泡は気相が単位体積あた りに駆動する周囲流体の体積が大きくなるため，気泡 の浮上によって対流がもたらされる。マイクロバブル の産業利用においてその効果をさらに引き出すために は，周囲流体との相互作用が如何なるときに顕在化し，

* 原稿受付 2010 年 4 月 19 日.

*1 学生員, 北海道大学大学院工学院(专060-8628 札幌市北区 北 13 条西 8).

*2 正員, 北海道大学大学院工学研究院.

E-mail : twatamura@ ring-me.eng.hokudai.ac.jp
あるいはその効果が増幅するかを究明しなければなら ない.ただし，球形マイクロバブルの運動方程式自体 は十分に確立されており，層流や孤立渦などの単純な 流れ場に対する応答は解析的に予想できる，著者らが 研究対象とするのは，乱流遷移に与える影響，すなわ ち流れ場が非線形領域で構造化するときのマイクロバ ブルと流れ場の干渉である。非線形領域における気液 の双方向相互作用は理論的に記述，予想することが困 難であり，実験による知見の獲得が必要である.

小さい気泡, $\mu \mathrm{m}$ オーダの気泡など，マイクロバブ ルにはさまざまな捉え方があるが，本研究では直径 $O$ $(10 \mu \mathrm{m})$ の気泡のことをマイクロバブルと呼び，それ よりも大きな気泡と区別して取り扱う。チャネル乱流 における過去の研究では, ボイド率 $0.02 \%$ 僅かなマ イクロバブルの注入に対して, 20\%もの大きな抵抗低 減効果が報告されている(2). 直径 $O(1 \mathrm{~mm})$ の気泡を 用いて $20 \%$ の抵抗低減をもたらすためには，10\%以上 のボイド率が必要であること(3)を考えると，マイクロ バブルと乱流渦の干渉が流れの制御の観点でいかに重 要であるかがわかる。ただしこの実験例を含め, マイ クロバブルによる流れ制御についてはその再現性や信 憑性の検証が十分とは言えず，さらにそのメカニズム について複数の仮説や推諭(4) (7) が提唱されているが 
包括的な理解には到達していない.

本研究ではマイクロバブルが流れ場に与える影響を 調べるため，テイラー・クエット流れ(TCF) を対象と して超音波流速分布計(UVP)を用いた速度場計測に より定量的実験を行う。本報では, TCF が持つ複数 の流動モードのうち, 波動テイラー渦流れ領域と変調 波動テイラー渦流れ領域について焦点を当て, 一連の 遷移シークエンスの初期段階におけるマイクロバブル の作用を明らかにする。

\section{2. テイラー・クエット流れ}

テイラー・クエット流れ(TCF) とは同軸回転二重 円筒間に形成される流れの総称である。図 1 は外円筒 を固定し内円筒を回転させた際の TCF を, 板状の微 粒子 (Kalliroscope 社製, Kalliroscope AQ-1000)を 用いて円筒横から可視化した写真である，内円筒の回 転速度増大に伴い, 流動モードはクエット流れ (Couette flow, CF), (a) テイラー渦流れ (Taylorvortex flow, TVF), (b) 波動テイラー渦流れ (Wavy vortex flow, WVF), (c) 変調波動テイラー 渦流れ (Modulated wavy vortex flow, MWVF) と遷 移する。

マイクロバブルが流れ場に与える影響を評価するた めに TCF を用いる利点として，以下の点が挙げられ る.（1）閉じた系であり，十分に流れの渦構造が発達 した状態に気泡を加えることができるため，その影響 をとらえやすい.（2）実験パラメータとして円筒の 回転数のみで様々な流れの状態を実現でき，さらにそ の流動モードの遷移について詳細に観察することがで きる.（3）単相では非常に多くの研究が行われてお り, 乱流遷移に関する潤沢な知見から, 気泡の影響を 議論しやすい. また，（4）TCF は旋回流れ, 単純せ 乙断流れ (CF), 渦 (Taylor-vortex)や流体中を伝播す る波 (周方向波動成分) など, 多くの基礎的な流れの要
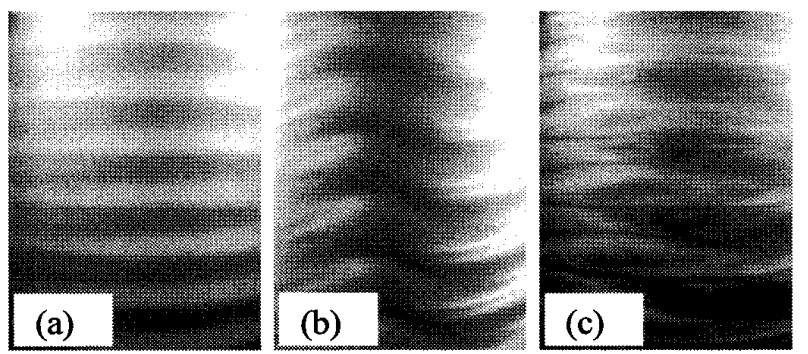

Fig. 1 Flow patterns in the Taylor-Couette system: (a) Taylor-vortex flow (TVF), (b) wavy vortex flow (WVF) and (c) modulated wavy vortex flow (MWVF)
素を含んでいる。そのため, マイクロバブルが TCF に与える影響を調べることにより，一般的な流れ場に おけるその影響を包括的に示すことが可能である.

気泡を含むTCF に打ける過去の研究では, 直径 $O$ $(100 \mu \mathrm{m})$ の気泡が浮力, 揚力, 圧力勾配などのバラン スにより,テイラー渦の決まった位置に集積するこ と(8)〜(10)や, 集積した気泡群の浮力により渦が伸長す ること ${ }^{(9)(10)}$, その結果として流動モードがスパイラル モードへ遷移すること(10) が知られている。さらに, これらの研究では渦と気泡の相互作用の結果として流 体の摩擦抵抗が低減されている(10) (13).このように, TCF は気泡が流れ場に与える影響を評価するための 系としてこれまでに多数用いられており，マイクロバ ブルと流れ場の相互作用を評価するために適した系と 考えられる.さらに，これまでの研究結果との比較に より，気泡サイズによる影響の違いについても言及で きる．特に本報では，マイクロバブルがテイラー渦の 時空間スケールに与える影響と, 高次モードへの遷移 に与える影響に分けて実験結果を整理する。

\section{3. 実験装置および方法}

実験装置の概略図と座標系を図 2 に示す。同軸回転 二重円筒は, 半径 $R_{i}=95 \mathrm{~mm}$ の $\mathrm{FRP}$ 製内円筒と半 径 $R_{o}=105 \mathrm{~mm}$ のアクリル製外円筒から構成され, 流体層厚さ $d\left(=R_{o}-R_{i}\right)=10 \mathrm{~mm}$, 半径比 $\eta(=$ $\left.R_{i} / R_{o}\right)=0.905$ である. 円筒高さは $h=200 \mathrm{~mm}$ であ り, アスペクト比 $\Gamma(=h / d)=20$ となる. 作動流体に は水（動粘性係数 $\nu=1.0 \times 10^{-6} \mathrm{~m}^{2} / \mathrm{s}$ )を用いた。流体 層底部に取り付けた直径 $100 \mu \mathrm{m}$ の白金ワイヤを陰極, ウォータージャケット内に設置した銅板を陽極とし て, 水の電気分解により水素気泡マイクロバブルを発 生させた，白金ワイヤは，流体層底部に設置した外半

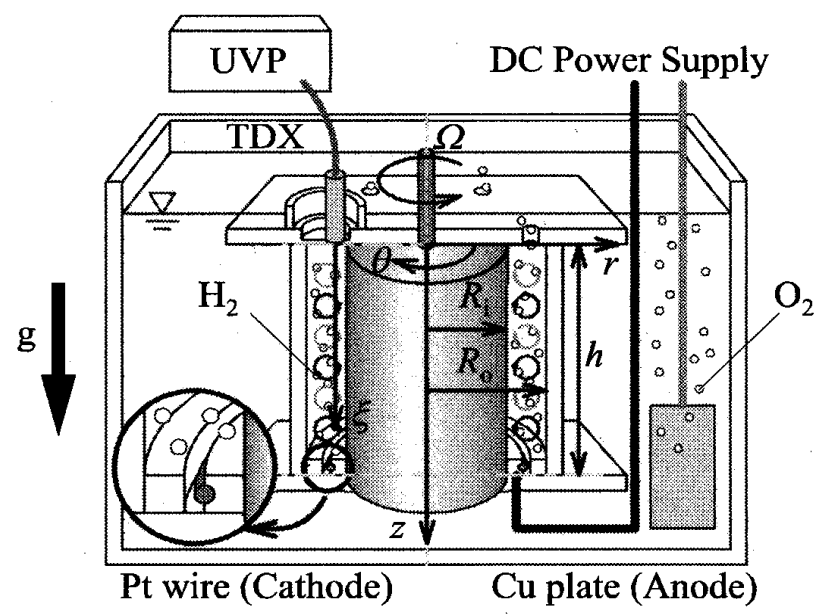

Fig. 2 Schematic sketch of experimental setup 


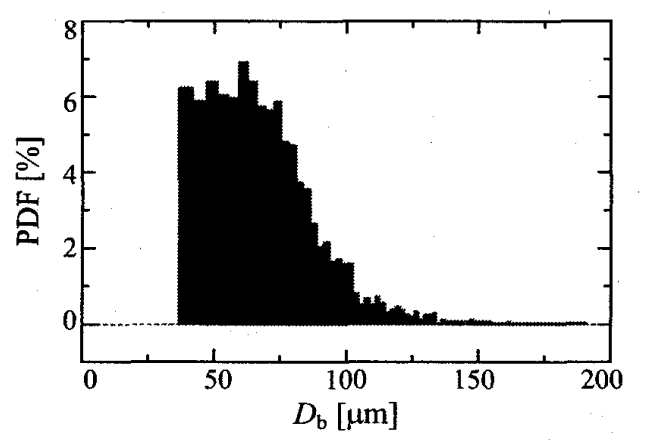

Fig. 3 Distribution of microbubbles' diameter

径 $R_{i}+d / 2$ の環状の台に一周巻きつけることで流体 層中央部に固定した。さらにこの環状台と同じ高さの 外輪を設置することで，白金線の設置による流れ場の 影響を抑えた。環状台と外輪との間隙は $2 \mathrm{~mm}$ であ る.バックライトを用いて気泡の影を撮影した画像か ら気泡径を求めた。気泡直径の確率密度分布を図 3 に 示す。ここから得られた気泡の平均直径は約 $60 \mu \mathrm{m}$ であった，電気分解のための電源として直流電源装置 （菊水電子工業社製，PAN600-2A）を用いた。電気分 解の理論式から, 発生した気泡の体積流量 $Q$ は気体 定数 $R$, 絶対温度 $T$, 絶対圧力 $P$, ファラデー定数 $F$, 電流 $I$ から式( 1 )で見積もられる.

$$
Q=\frac{1}{2} \frac{R T}{P} \frac{I}{F}
$$

本実験装置は電極間距離が大きくまた気泡発生から十 分時間を置いて計測しているため, マイクロバブルは 周方向に均一に発生しその体積流量は一定と考元られ る(14). 式( 1 )とマイクロバブルの静止流体中におけ る終端速度 $u_{T}^{(15)}$ から, 気泡の自由浮上状態における ボイド率 $\alpha$ は式(2)で表される.

$$
\alpha=\frac{Q}{\pi\left(R_{o}^{2}-R_{i}^{2}\right) u_{T}}
$$

本実験では最大の気泡発生条件において，それぞれ $Q$ $=2.5 \mathrm{~mm}^{3} / \mathrm{s}, \alpha=0.012 \%$ と見積もった．密度の異な る別の分散相を含んだ際の流体の実効動粘度は, Taylor による理論式(16) と, 作動流体の平均密度によ って表すことができる. 本研究ではボイド率が極めて 小さく, 気泡を含む条件における実効動粘度の変化は 単相時の1.00024倍となることからその影響は無視で きると考えられる．速度場の取得には超音波流速分布 計(UVP, MET-FLOW 社製, UVP-DUO)を用いた。 基本周波数 $4 \mathrm{MHz}$, 素子径 $5 \mathrm{~mm}$ の超音波トランス デューサ(TDX, MET-FLOW 社製 TX-4-5-8-40)を 流体層上部から $z$ 軸と平行に設置し, 超音波の伝播線 ( $\xi$ 軸)上の各時刻 $t$ における速度分布 $u_{z}(z, t)$ を計測

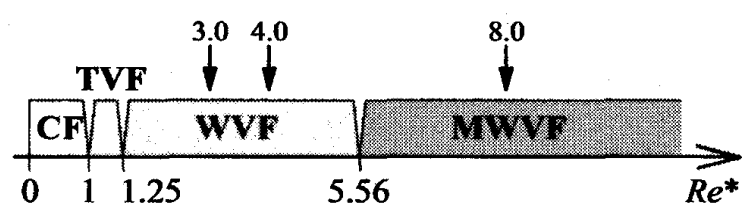

Fig. 4 Normalized experimental range

した. $u_{z}$ は $z$ 軸正方向を正とし, 計測条件は時間分 解能 $72 \mathrm{~ms}$, 空間分解能 $0.72 \mathrm{~mm}$, 速度分解能 0.39 $\mathrm{mm} / \mathrm{s}$ とした。UVP のトレーサとして樹脂製多孔質 粒子(粒径 60〜 $150 \mu \mathrm{m}$ ，比重 1.02) を用いた。なお， マイクロバブルの直径は UVP の検査体積や超音波の 基本波長と比較して十分小さい。また，マイクロバブ ルの音響固有振動数 ${ }^{(17)}$ は超音波の基本周波数と大き く異なる.このことから, マイクロバブルの混入は UVPによる流速データにランダム誤差を与えること はあっても，偏り誤差を与えることはないことを付記 しておく.

本研究では外円筒を固定し，内円筒のみをモー夕に より回転周波数 $\Omega$ で駆動した。この場合レイノルズ 数 $R e$ は式(3)のように定義される。

$$
R e=\frac{U d}{\nu}=\frac{2 \pi \Omega R_{i}\left(R_{o}-R_{i}\right)}{\nu}
$$

なお本研究では, CF から TVFへ遷移する際の臨界 レイノルズ数 $R e_{c}=134.5^{(18)}$ により規格化したレイノ ルズ数 $R e^{*}=R e / R e_{c}$ を用いて実験結果を整理する. また, TVFからWVFへ, WVFから MWVFへと 遷移する臨界レイノルズ数 $R e_{w}, R e_{m}$ は，それぞれ $R e_{w}=168.2^{(19)}, R e_{m}=747.5^{(20)}$ となっている. 計測 条件は, この半径比においてWVFおよび 流れ場を形成する条件である $R e^{*}=3.0,4.0,8.0$ と した。実験範囲の概略図を図 4 に示す。

\section{4. 実 験 結 果}

図 5 に $R e^{*}=3.0$ (波動テイラー渦流れ, WVF)の条 件にお法りる時空間速度分布を示す。横軸の時間 $t$ は内 円筒回転周期 $1 / \Omega$ で, 縦軸の距離 $z$ は流体層厚さ $d$ で無次元化してあり, 上下の固定壁となる端面の影響 を無視しうる範囲として，端面から十分離れた $5 \leq$ $z / d \leq 15$ の範囲を示している.色の濃淡は速度 $u_{z}$ を 表し, 内円筒壁面速度 $2 \pi \Omega R_{i}$ で無次元化してある. 図 5(a)の単相時における結果から, 空間方向に正負 の值が繰り返されていること，また時間方向にみると 正負の領域が空間方向に振動していることがわかる. このことから，一定の空間波長を持つテイラー渦の渦 対が，一定周期で軸方向に振動していることがわか 
る.また, 図 5(b)の二相条件（ボイド率 $\alpha=0.0024 \%$ ) の結果に抬いても同様のことがわかるが，流れ場全体 において上昇流 $\left(u_{z}<0\right)$ が増加していることがわか る.さらに流れ場の中に黒い線(例を白矢印で示す), すなわち局所的な上昇流を確認することができる。こ れは上昇するマイクロバブル，あるいはマイクロバブ ル群を示していると考えられる．本研究はこの時空間 速度分布を解析し，マイクロバブルが流れ場に及ぼす 影響を評価する。

$4 \cdot 1$ 渦の軸方向変化 図 5 (a) 時間平均した 時間平均速度分布 $\bar{u}_{z}$ を図 6 に示す．縦軸は内冈筒壁 面速度 $2 \pi \Omega R_{i}$ で無次元化した $\bar{u}_{z}$, 横軸は流体層厚さ

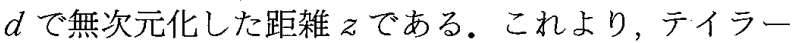
渦の渦対が作り出す流れ場は，内円筒近傍において軸 方向に正負の速度分布を繰り返すことがわかる.ここ で，極大と極小の值をとる距離をテイラー渦の軸方向 波長 $\lambda_{z}$ の半值とする. 各ボイド率 $\alpha$ に対する $\lambda_{z}$ をプ ロットしたものを図 7 に示す. 図 7 において, 丸が単 相時, 三角形が二相条件の值を，また菱形がその差
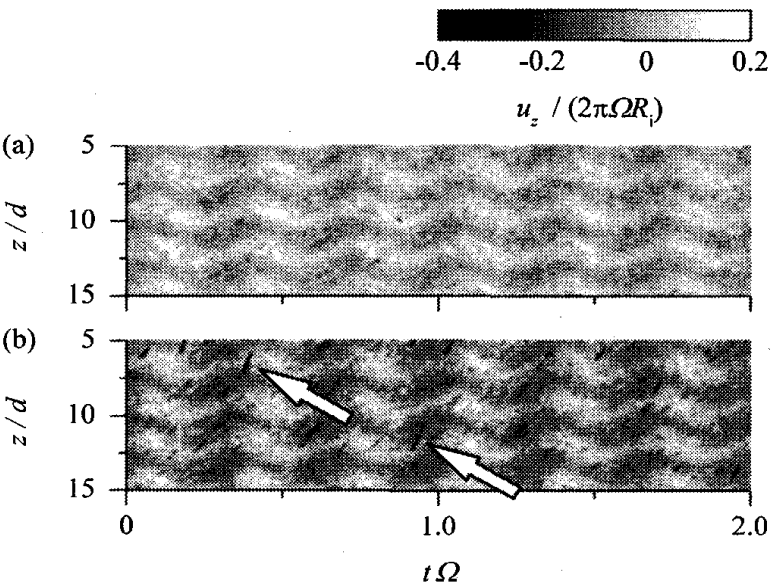

Fig. 5 Spatio-temporal velocity distribution in the condition (a) without or (b) with bubbles ( $\alpha=$ $0.0024 \%$ ) at $R e^{*}=3.0$ (WVF), where arrows show rising bubbles

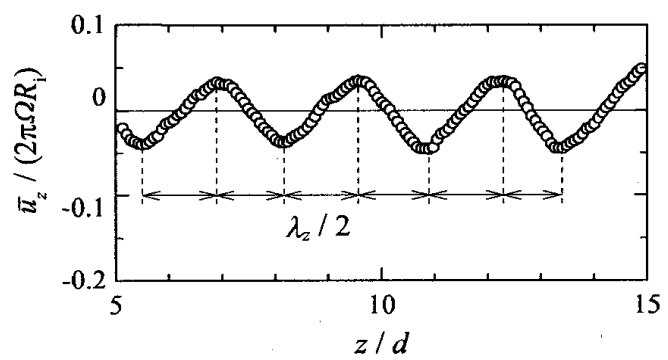

Fig. 6 Time averaged velocity distribution of the axial velocity component in single-phase condition at $R e^{*}=3.0$ (WVF), where $\lambda_{z}$ is the axial wavelength of the Taylor-vortex
$\Delta \lambda_{z}\left(=\lambda_{z}-\lambda_{z \text { bubble }}\right)$ を示している.図 7 から $\Delta \lambda_{z}$ は計 測の空間分解能 $\Delta z$ の範囲内であり，テイラー渦の軸 方向波長はマイクロバブルによる影響を受けていない と言える。

直径 $O(100 \mu \mathrm{m})$ 以上の気泡を含む TCF の過去の研 究では，気泡群が渦運動と干涉して特定の位置，例え ば渦中心やテイラー渦による外向き流れの内円筒近傍 に集積し，それによる浮力が渦を軸方向に伸長させる ことが報告されている(9)(10). こ北対してマイクロバ ブルの場合では，渦の大きさに変化が表れない。これ はマイクロバブル混入の体積率が小さいこと,ならび に本研究ではフルード数が 0.1 以下と小さいため, 前 述のような渦の特定の位置への集積を生じにくいこと による(8) (10).このように流れの主要な構造(大きなエ ネルギを保有するモード)の空間スケールに対してマ イクロバブルは直接的な影響を与えることはなく，受 動的な運動しか持たない.このことは従前からマイク ロバブルが流れの可視化におけるトレーサとして利用 できることを支持する結果と言えよう。

$4 \cdot 2$ 周方向波動の変化 図 5(a) 時間方向に フーリエ変換し，空間平均したものを図 8 に示す。縦 軸は速度変動のパワーを内円筒壁面速度 $2 \pi \Omega R_{i}$ の二 乗で, 横軸は周波数 $f$ を内円筒回転周波数 $\Omega$ で無次 元化している.ここで, 最大の速度変動パワーを示す 周波数をテイラー渦の基本波動周波数 $f_{w}$ とし，その 高調波をそれぞれ $2 f_{w} ， 3 f_{w}$ とする. また $f / \Omega=1$ 付近 にピークが確認できるが，これは円筒の回転周波数 $\Omega$ と考えられる。図 9 にボイド率 $\alpha$ に対する $f_{w}$ の変化 を示す．緃軸は $\Omega$ で無次元化した $f_{w}$ を表し，横軸は $\alpha$ を表している。 丸が単相時, 三角形が二相条件の值 で，その差 $\Delta f_{w}\left(=f_{w}-f_{w \text { bubble }}\right)$ を菱形で示した。図 9

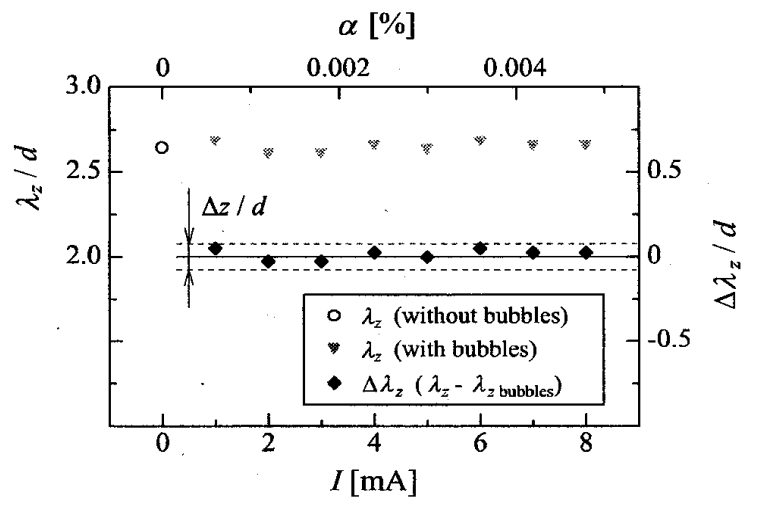

Fig. 7 Axial wavelength of the Taylor-vortices in the condition with or without bubbles, and difference of the axial wavelength between the conditions at $R e^{*}=3.0$ (WVF), where $\Delta z$ is the spatial resolution of the measurement 
より， $\Delta f_{w}$ が計測の周波数分解能 $\Delta f$ よりも十分小さ く,テイラー渦の周方向波動周波数はマイクロバブル の存在による影響を受けていないことががわかる.

以上 $4 \cdot 1$ 節扔よび $4 \cdot 2$ 節の結果から, マイクロバブ ルの存在はテイラー渦の軸方向, 周方向の構造に対し て有意な変化を与えないという結果になった。これは テイラー渦が僅がな体積率のマイクロバブルの混入に 対して十分に強勒で安定な構造を保ち，その基本構造 それ自体は容易に崩壊しないことを示すものである. 対比して，著者らによる大きな気泡の実験(10)では，気 泡群が波動テイラー渦流れをスパイラルモードに変態 させるなど，単相流におけるその境界条件では観察さ れない新たな流動モードを作り出すことがわかってい る. 従ってマイクロバブルの場合では僅かな分散量に 留める限り，そのような二相流特有のモードを作り出 す機能はなく, 単相流の流動モードを維持すると言え る.

$4 \cdot 3$ マイクロバブルの上昇パターンー一方で,

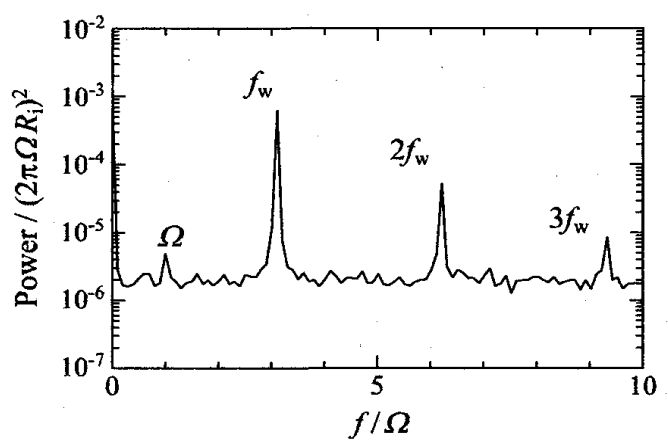

Fig. 8 Power spectrum of the axial velocity fluctuation at $R e^{*}=3.0$ (WVF), where $f_{w}$ and $\Omega$ are basic wave frequency of the Taylor-vortices and rotation frequency of inner cylinder

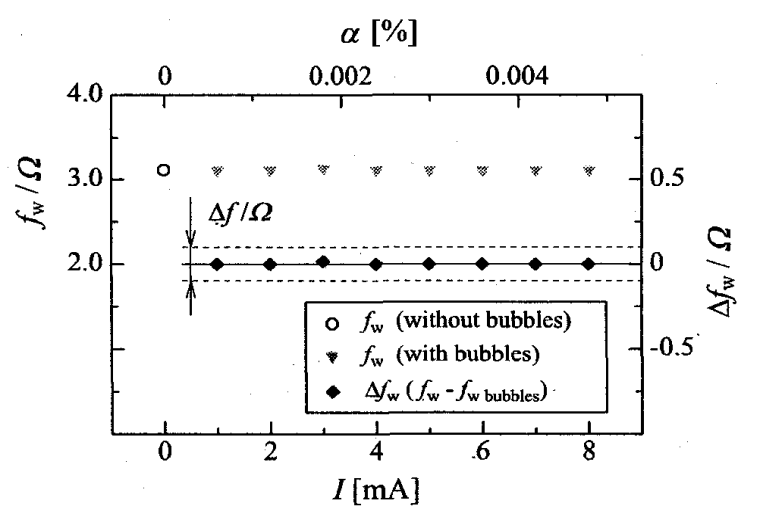

Fig. 9 Frequency of the basic wave component in the condition with or without bubbles, and the difference of the frequency between the conditions at $R e^{*}=3.0$ (WVF), where $\Delta f$ is the frequency resolution of the measurement
マイクロバブルは時間平均速度分布を上昇流方向に変 化させる，図 10（a )，（d）は流体層内に打ける渦(白 矢印)とマイクロバブルの挙動(黒矢印)の概念図, （b），（e）は時間平均速度分布 $\bar{u}_{z},(\mathrm{c}) ，(\mathrm{f})$ は速度 変動成分の RMS 值 $u_{z, \mathrm{RMS}}$ を表している，それぞれの 縦軸は流体層内に㧈ける軸方向位置 $z$ を示し, 図 10(a)，（d）の横軸は流体層半径方向位置 $r-R_{i}$ を $d$ で無次元化したもの，(b)，(e)押よび(c)，(f)の 横軸は $\bar{u}_{z}, u_{z, \mathrm{RMS}}$ を内円筒壁面速度 $2 \pi \Omega R_{i}$ で無次元 化したものである. 図 10 上段( a ) （c）は $R e^{*}=$ 3.0 , 下段 $(\mathrm{d}) \sim(\mathrm{f})$ は $R e^{*}=4.0$ (共に WVF, 図 1 お よび図 4 参照)の結果を示している.

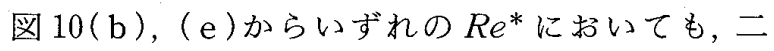
相条件 (ボイド率 $\alpha=0.0024 \%$ )では $\bar{u}_{z}$ が上昇流 $\left(u_{z}<0\right)$ 方向へ変化していることがわかる. しかし, 図 10 (b)の $R e^{*}=3.0$ における二相条件では単相条 件からの $\bar{u}_{z}$ の変化量がほぼ一定であるが, (e)の

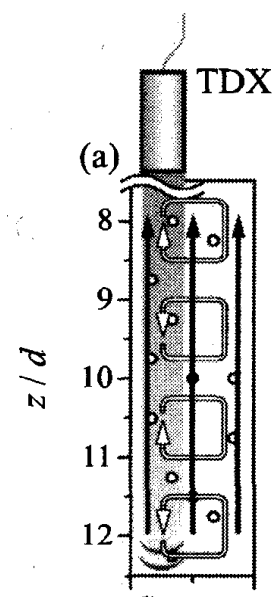

(d)

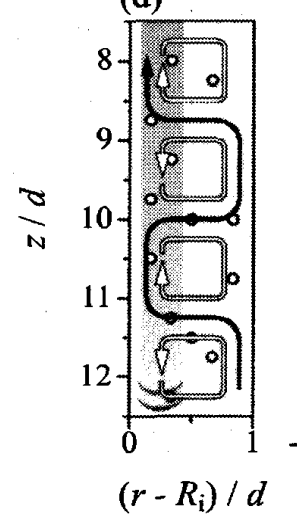

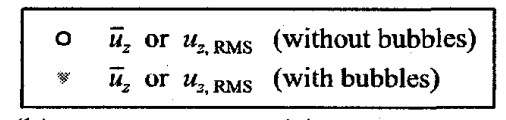

(b)

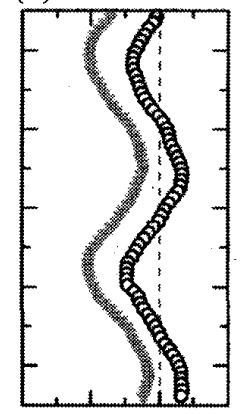

(e)

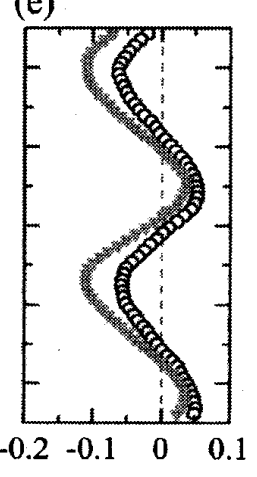

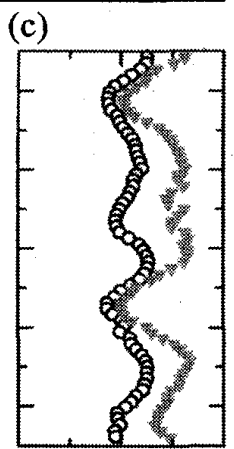

(f)

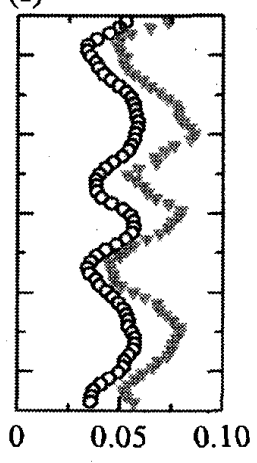

Fig. 10 (Left) schematics of the Taylor-vortices and the rising patterns of microbubbles at (a) $R e^{*}=3.0$ and (d) 4.0 , (center) time averaged velocity distributions in the condition with or without bubbles at (b) $R e^{*}=3.0$ and (e) 4.0 , (right) profiles of the standard deviation of the velocity fluctuation in the condition with or without bubbles at (c) $R e^{*}=3.0$ and (f) 4.0 
$R e^{*}=4.0$ における二相条件では単相時に上昇流を形 成した領域において， $\bar{u}_{z}$ の上昇流方向への変化量が 下降流領域に打ける変化量より大きいことがわかる。 これら $\bar{u}_{z}$ の変化量はいずれもマイクロバブルの上昇 速度程度であり，この上昇運動が $\bar{u}_{z}$ を変化させてい ると考えられる。また図 $10(\mathrm{c})$ から，Re*=3.0では 下降流領域における $u_{z, \mathrm{RMS}}$ の変化が大きいことがわか る.しかし図 10 (f) の $R e^{*}=4.0$ となる条件では, (c)注ど顕著な変化を確認できない.これは図

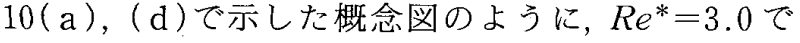
は流体層内に分散したマイクロバブル群のうち下降流 領域を上昇するものが $u_{z, \mathrm{RMS}}$ の増加をもたらし，Re* $=4.0$ ではマイクロバブル群が空間的な濃度パターン を形成し渦の上昇流領域を移動するため, その上昇挙 動が $u_{z, \mathrm{RMS}}$ に顕著な変化を与えないためと考えられ る. なお WVF の変動時間スケールから算出した, 単 一気泡のストークス数は $O\left(10^{-4}\right)$ 程度と極めて小さ く,流れの変動に対してはほぼそれに追従すると考え られる、しかしながら, 気泡に働く圧力勾配や抗力な どにより流れと気泡の運動にはごく僅かなずれがあ り，レイノルズ数の増加による流れ場の変化からその ずれが増幅され気泡の配置が高度に組織化されること でここに示したようなパターンが形成されるものと 考えている.

\section{4 変調波動パワーの低下 図 11 は, $R e^{*}=$} 8.0 (変調波動テイラー渦流れ, MWVF, 図 1 扔よび 図 4 参照)における各ボイド率 $\alpha$ に対するテイラー渦 の軸方向波長 $\lambda_{z}$ を表している. また, 図 12 は $R e^{*}=$ 8.0.に抢けるテイラー渦の周方向波動成分のスペクト ルである。このスペクトルにおいて, 最大の速度変動 パワーを示す周波数をテイラー渦の基本周波数 $f_{w}$ と

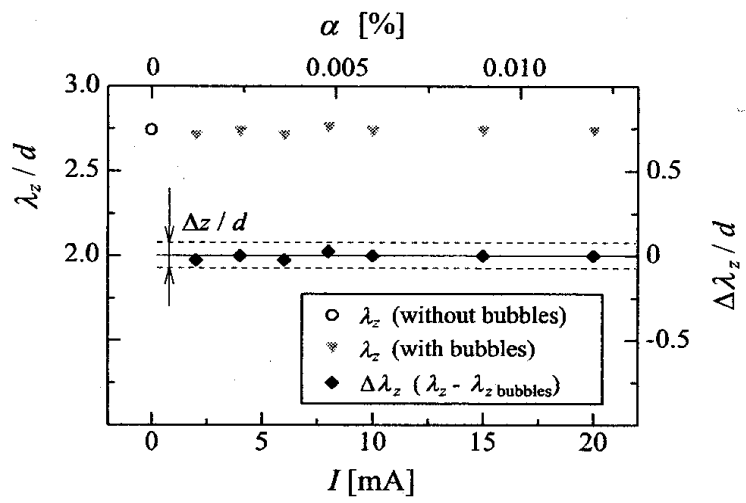

Fig. 11 Axial wavelength of the Taylor-vortices in the condition with or without bubbles and difference of the axial wavelength between the conditions at $R e^{*}=8.0$ (MWVF), where $\Delta z$ is the spatial-resolution of the measurement
して, 各 $\alpha$ に対する $f_{w}$ の值をプロットしたものを図 13 に示す. $4 \cdot 1$ 節や $4 \cdot 2$ 節の結果と同様に, ここでも マイクロバブルの有無による明瞭な変化は見られな い.

図 12 のスペクトルにおいて, $f_{w}$ とその高調波以外 のピークが見られる.これらは $f_{w}$ と $f / \Omega=0.4$ 付近 の低周波成分 $f_{m}$ との干渉によって生じるものであり， 全てが $f_{w}$ と $f_{m}$ の線形和で表すことができる。この $f_{m}$ 成分が周方向波動に変調をもたらしている変調波 動成分である。図 14 は $f_{w}$ およ゙ $f_{m}$ 成分のパワーと ボイド率 $\alpha$ の関係を表している。 また， $f_{m}<f<f_{w}$ に おける最小パワーを流れの背景成分 (background component）と定義した。

図 14 から， $\alpha$ の増加に伴い $f_{w}$ のパワー, Power $\left(f_{w}\right)$ が単調増加し，その後ある值に漸近すること, $f_{m}$ のパワー, Power $\left(f_{m}\right)$ が単調減少していることがわか る. TCFに抽， $f_{m}$ 成分は $\operatorname{Re}$ の増加によっても たらされる流れの複雑化の結果として発現し， $f_{w}$ 成

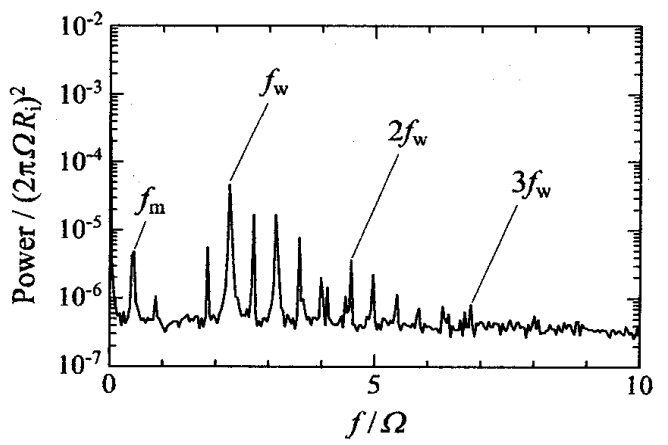

Fig. 12 Power spectrum of the axial velocity fluctuation at $R e^{*}=8.0(\mathrm{MWVF})$, where $f_{w}$ and $f_{m}$ are the basic wave frequency and the modulation wave frequency of the Taylor-vortices

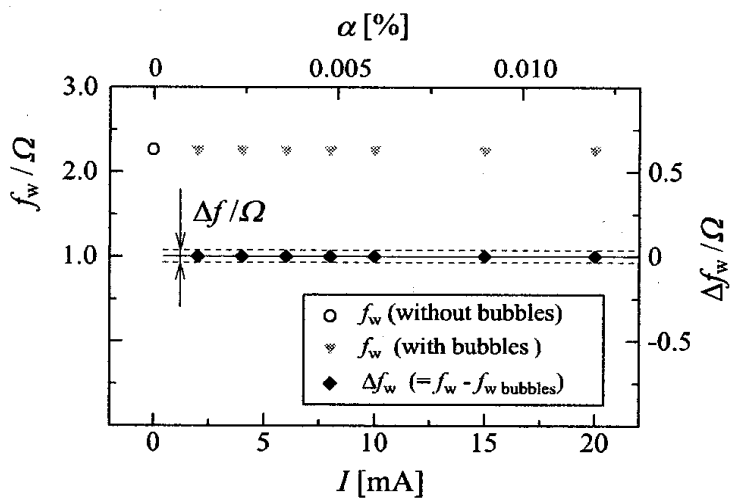

Fig. 13 Frequency of the basic wave component in the condition with or without bubbles and the difference of the frequency between the conditions at $R e^{*}=8.0$ (MWVF), where $\Delta f$ is the frequency resolution of the measurement 


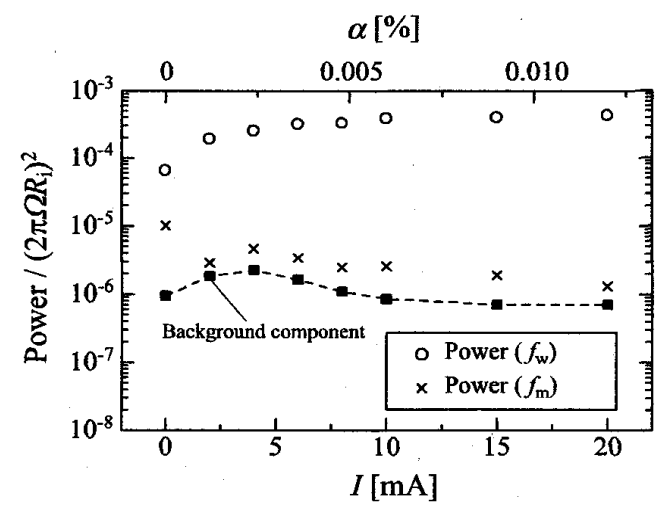

Fig. 14 Power of the basic and the modulation wave component versus void fraction at $R e^{*}=8.0$ (MWVF)

分が有するエネルギを他の波動成分に分散させてい る.そして,さらなる $R e$ の増加によって第三の波動 成分が出現し, 流れ場はカオス, 乱流状態へと遷移し ていくつまり， $f_{m}$ のパワーが減少し， $f_{w}$ 成分にエ ネルギが集中するこの現象は，マイクロバブルによる 流れの遷移の抑制と考えられる。また，今回得られた いくつかのパワースペクトルでは背景成分と $f_{m}$ のパ ワーに明瞭な差がなくなり， $f_{m}$ のピークを判断でき なくなることがあった。この場合は，単相時に $f_{m}$ が 現れた周波数の前後の值から機械的にパワーを抜き出 している，そして，実験の条件として単相時における 流れの状態は MWVFであるが，このときのスペクト ル形状はWVFのものと区別できなくなる。つまり， マイクロバブルが流れの遷移を抑制し，流動モードを 低次のモードに変化させることを意味している。ま た,これは図4に示すWVFへ遷移する臨界 Re, $R e_{m}$ が 1.4 倍, 高 $R e$ 側に変化したと考えられる.す なわち, WVF から MWVF の領域がマイクロバブル の存在により $R e^{*}=8.0$ 付近まで拡大していると理解 できる，TCFに扔る波動は流体軸受において振動 や騷音の原因となっている. $f_{m}$ 成分の減少は低周波 数領域におけるこれらの問題を低減する効果があると 期待できる。

本研究の系において流体層内でマイクロバブルが一 様に分布する場合では，実効動粘度の変化率は単相時 の $O\left(10^{-4}\right)$ 倍程度と見積もられる.さらに, マイクロ バブルの直径が流体層厚さの $O\left(10^{-3}\right)$ 倍と極めて小さ いことから，その存在自体が渦や波動といった流れの 構造に与える影響は無視できると考えられる。そのた め, $f_{m}$ のパワーが減少するメカニズムは, 図 $10(\mathrm{a})$, (d)のように流体層内に存在するマイクロバブルが明 瞭で規則的なパターンを形成して上昇することに起因
すると考えられる．すなわち気液相互作用に高度な規 則性が形成され，無秩序に運動する場合に比べて渦運 動に対して選択集中的な運動量交換をもたす，という 解釈ができる. 図 10 に示した結果から，比較的高 $R e$ においては流体層内でマイクロバブルは渦の上昇流領 域を移動すると考えられ，この際に流体層内の各所で 局所ボイド率が変化する，流体層内でマイクロバブル が軸方向に一列となって上昇すると仮定すると, 最大 気泡発生時の局所ボイド率は約 $2 \%$ と見積もられ, 平 均ボイド率の約 200 倍となる.このボイド率における 実効動粘度の変化は $4 \%$ 程度と小さいが，しかし，そ こには局所的に大きな浮力が作用し，渦運動に対して 規則性のある浮力分布をもたらすこととなる。視点を 変えれば，マイクロバブルはTCF内において時空間 的に組織化された濃度パターン(ボイド波) $)^{(21) \sim(24) を ~}$ 形成しながら浮上すると考えられる。このパターンは 気泡サイズよりも明らかに大きなスケールの波長をも った対流をもたらす(22) (24).つまり，局所ボイド率の 変化によって流体層内に気泡の浮力によってもたらさ れる対流運動が生じ，これと TCFに打ける周方向波 動の非線形な干渉により変調波動成分の出現と成長が 抑制されていると考えられる。

\section{5. 結論}

同軸回転二重円筒間に形成されるテイラー・クエッ ト流れに直径 $O(10 \mu \mathrm{m})$ のマイクロバブルを注入し, 超音波流速分布計を用いて流れ場の速度分布を計測し た。その結果として，以下のことが明らかとなった。

（1） マイクロバブルの体積率が僅か (0.01\%程度) であれば，テイラー渦がもつ波長や波数などの基本的 な空間構造を変化させることはない.このことはマイ クロバブル混入による液体物性 (平均密度や実効粘度) の変化率が十分に小さく, 単相流の流動モードをその まま維持するためである.また，個々のモードはマイク ロバブルに対して安定で強靯な構造を持つためである.

（2）変調波動テイラー渦流れの領域において，マ イクロバブルは基本波動パワーを増加させ, 変調波動 パワーを隇少させる。すなわち，高次モードである変 調波動の発生を妨げることから，マイクロバブルは流 れの非線形干渉に伴う高次モードへの遷移を抑制する 作用がある。（1）と合わせて考えると，マイクロバブ ルの作用とは, 流動の各モードにおける基本構造を変 化させることはないが，モード遷移に対しては僅かな ボイド率でも大きな影響となって表れる。

（3）（2）のように流れの遷移に対してマイクロバ ブルの影響が顕在化して観測される理由は，マイクロ 
バブルが液体との間で僅かな相対速度しか許されず, それゆえ渦運動と連動した高度な規則性を伴って運動 するためである。それにより，僅かなボイド率であっ ても空間的に構造化された浮力分布を形成し, 遷移に 対して明瞭な変化をもたらすものと考えられる。

なお，本報では TCF における複数の遷移点のうち， 波動テイラー渦流れから変調波動テイラー渦流れへの 遷移に焦点を当てた。これは，波動テイラー渦流れが 単一の周方向波動成分しか持たないことに対して, 変 調波動テイラー渦流れが非線形干渉による複数の波動 成分を持ち，その間の遷移を調べることで乱流遷移の 初期段階に与える影響を議論することができるためで ある、今回の知見の位置付けをさらに明確にするため に, 今後,さらに幅広い範囲のレイノルズ数を扱い, 他の遷移点に与える影響を調查する必要がある。

\section{謝辞}

本論文をまとめるにあたり，Tom Mullin 教授(イ ギリス, マンチェスター大学)ならにび, 杉山和靖博士 (東京大学)上り貴重な助言を頂いた。また, 本研究は 科学研究費補助金(基盤 B 21280077)の支援によるも のである.ここに感謝の意を表する。

\section{文献}

(1) Matsumoto, Y., Takagi, S., Yoshizawa, S., Kaneko, A., Takemura, F., Murai, Y., Kawamura, T., Kodama, Y., Kouda, K., Ida, H., Kawasaki, T. and Kaneko, Y., Frontiers of Mechanical Engineering, Vol. 3, Frontiers of Micro-bubbles, (2009), Kyoritsu Syuppan Co., Ltd.

(2) Murai, Y., Ohishi, Y., Sasaki, T., Kodama, Y. and Yamamoto, F., Turbulent Shear Stress Profile in Horizontal Bubbly Channel Flow, Proceedings of 6th International Symposium of Smart Control of Turbulence, (2005), pp. 289-295.

(3) Murai, Y., Fukuda, H., Oishi, Y., Kodama, Y. and Yamamoto, F., Skin Friction Drag Reduction by Large Air Bubbles in a Horizontal Channel Flow, International Journal of Multiphase Flow, Vol. 33 (2007), pp. 147-163.

(4) McCormick, M. E. and Bhattacharyya, R., Drag Reduction of a Submersible Hull by Electrolysis, Navy Enginnering Journal, Vol. 85 (1973), pp. 11-16.

(5) Xu, J., Maxet, M. and Karniadakis, G., Numerical Simulation of Turbulent Drag Reduction Using MicroBubbles, Journal of Fluid Mechanics, Vol. 468 (2002), pp. 271-281.

(6) Ferrante, A. and Elghobashi, S., On the Rysical Mechanism of Drag Reduction in a Spatially Developing Turbulent Boundary Layer Laden with Microbubbles, Journal of Fluid Mechanics, Vol. 503 (2004), pp. 345355.

( 7 ) Serizawa, A., Inui, T. and Eguchi, T., Flow Characteristics and Pseudo-Laminarization of Vertically Upward Air-Water Milky Bubbly Flow with Micro Bub- bles in a Pipe, Konsoryu (in Japanese), Journal of Japan Society of Multiphase Flow, Vol. 19, No. 4 (2006), pp. 335-343.

(8) Climent, E., Simonnet, M. and Mangaudet, J., Preference Accumulation of Bubbles in Couette-Taylor Flow Patterns, Physics of Fluids, Vol. 19 (2007), pp. 083301083312.

(9) Djeridi, H., Gabillet, C. and Billard, Y., Two-Phase Couette-Taylor Flow: Arrangement of the Dispersed Phase and Effect on the Flow Structure, Physics of Fluids, Vol. 16 (2004), pp. 128-139.

(10) Murai, Y., Oiwa, H. and Takeda, Y., Frictional Drag Reduction in Bubbly Taylor-Couette Flow, Physics of Fluids, Vol. 20 (2008), pp. 034101-034112.

(11) Sugiyama, K., Calzavarini, E. and Lohse, D., Microbubbly Drag Reduction in Taylor-Couette Flow in Wavy Vortex Regime, Journal of Fluid Mechanics, Vol. 608 (2008), pp. 21-41.

(12) Van den Berg, T. H., Luther, S., Lathrop, D. P. and Lohse, D., Drag Reduction in Bubbly Taylor-Couette Turbulence, Physical Review Letter, Vol. 94 (2005), pp. 044501-044504.

(13) Van den Berg, T. H., Luther, S., Lathrop, D. P. and Lohse, D., Bubbly Turbulent Drag Reduction is a Boundary Effect, Physical Review Letter, Vol. 98 (2007), pp. 084501-084504.

(14) Nagai, N., Takeuchi, M., Kimura, T. and Oka, T., Existence of Optimum Space between Electrodes on Hydrogen Production by Water Electrolysis, International Journal of Hydrogen Energy, Vol. 28 (2003), pp. 35-41.

(15) Hadamard, J.S., Comptes Rendus de l'Academie des Sciences, Paris, Vol. 152 (1911), pp. 1735-1738.

(16) Taylor, G. I., The Formation of Emulsions in Definable Field of Flow, Proceedings of the Royal Society of London, Series A, Vol. 146 (1934), pp. 501-523.

(17) Brennen, C.E., Cavitation and Bubble Dynamics, (1995), Oxford University, Oxford.

(18) Di Prima, R. C. and Swiney, H. L., Instabilities and Transition in Flow Between Concentric Rotating Cylinders, Topic in Applied Physics, Vol. 45 (1979), pp. 139-180.

(19) Andereck, C. D., Liu, S. S. and Swinney, H. L., Flow Regims in a Circular Couette System with Independently Rotating Cylinders, Journal of Fluid Mechanics, Vol. 164 (1986), pp. 155-183.

(20) Morinaga, M., Takada, D., Tasaka, Y. and Takeda, Y., Oscillating Taylor-Couette Flow, Nagare (in Japanese), Journal of Japan Society of Fluid Mechanics, Vol. 24, No. 2 (2005), pp. 158-194.

(21) Biesheuvel, A. and Gorissen, W. C. M., Void Fraction Diturbance in a Uniform Bubbly Fluid, International Journal of Multiphase Flow, Vol: 16, No. 2 (1990), pp. 211-231.

(22) Alam, M. and Arakeri, V. H., Observations on Transition in Plane Bubble Plumes, Journal of Fluid Mechanics, Vol. 354 (1993), pp. 363-374.

(23) Murai, Y. and Matsumoto, Y., Numerical Study of the Three-Dimensional Structure of a Bubble Plume, Transactions ASME, Journal of Fluids Engineering, Vol. $122(2000)$, pp. 754-760.

(24) Robinson, M., Fowler, A.C., Alexander, A. J. and O'Brien, S. G., Waves in Guiness, Physics of Fluids, Vol. 20 (2008), pp. 067101-067115. 